\title{
Factors related to transfusion in very low birthweight infants treated with erythropoietin
}

Department of Neonatology, VirchowKlinikum der

Humboldt Universităt, Augustenburger Platz 1, D-13353 Berlin, Germany. R F Maier

M Obladen

D Messinger

C A J Wardrop

Correspondence to: Dr R F Maier.

Accepted 30 January 1996

\author{
R F Maier, M Obladen, D Messinger, C A J Wardrop on behalf of the European \\ Multicentre rhEPO Study Group
}

\begin{abstract}
The need for red cell transfusions is reduced but not eliminated by recombinant human erythropoietin (rhEPO) in very low birthweight (VLBW) infants. To detect factors associated with the decision to transfuse VLBW infants during rhEPO treatment and to explain rhEPO 'nonresponders', the subgroup of those 120 VLBW infants who were treated with rhEPO 750 IU/kg per week in the second European Multicentre rhEPO Trial was evaluated. Sixty $(50 \%)$ infants received at least one transfusion during erythropoietin treatment. Transfusion was frequent in infants with extremely low birthweight (79\% for $750-999 \mathrm{~g})$, low gestational age (70\% for $\leqslant 28$ weeks), low initial haematocrit or low initial reticulocyte count $(61 \%$ for haematocrit $\leqslant \mathbf{0 . 4 8}$ and reticulocytes $\leqslant 9 \%$, respectively). Considerable differences among centres were found for sampling blood loss, iron supply, and transfusion rate, which ranged from $13 \%$ to $73 \%$ and was related to the volume of diagnostic blood loss $(19 \%$ vs $80 \%$ for blood loss $<1$ vs $\geqslant 1 \mathrm{ml} / \mathrm{kg}$ per day). The prognostic variables birthweight, initial haematocrit, and gestational age were found to be most predictive for transfusion.

To improve rhEPO response in VLBW infants, there is a need to minimise diagnostic blood loss, to prevent iron deficiency, and to develop rational criteria for transfusion in preterm infants.

(Arch Dis Child 1996; 74: F182-F186)
\end{abstract}

Keywords: anaemia of prematurity, transfusion, recombinant human erythropoietin.

Although very low birthweight (VLBW) infants receive frequent transfusions for the anaemias of prematurity, there are no generally accepted transfusion guidelines available and the transfusion practices vary considerably. ${ }^{12}$ In 1990 Brown et al investigated predictors of the perceived need for transfusion in preterm infants to identify babies who might benefit from recombinant human erythropoietin (rhEPO). ${ }^{3}$ Recently, rhEPO, 300-1400 IU/kg bodyweight a week, has been shown to be effective and safe in preterm infants, and to reduce their need for red blood cell transfusions. ${ }^{4-12}$ However, rhEPO treatment did not obviate the need for transfusion in all infants. Analysis of 'non-responders' may help to optimise rhEPO treatment in preterm infants.
Findings on efficacy and safety of the second European Multicentre rhEPO Trial have been published recently. ${ }^{7}$ We now report a subgroup evaluation of the rhEPO treated infants. The purpose of this additional analysis was to detect prognostic and concomitant factors associated with the decision to transfuse red blood cells during rhEPO treatment, and to assess the impact of centre-specific variations in management and individual problems in 'non-responders'.

\section{Methods}

We evaluated those 120 VLBW infants who were treated with rhEPO (750 IU/kg a week) during their first six weeks of life in the second European Multicentre rhEPO Trial. ${ }^{7}$ Fifty (42\%) were girls. Birthweight was 750-999 $\mathrm{g}$ in $34,1000-1249 \mathrm{~g}$ in 43 , and $1250-1499 \mathrm{~g}$ in 43 infants. Thirty three infants did not complete the protocol due to predefined criteria.

Guidelines for red cell transfusions were derived from the experience of the participating neonatologists: ventilated infants and those aged under 2 weeks with signs of anaemia were transfused when the haematocrit was $<0.40$ and/or haemoglobin concentration was $<140 \mathrm{~g} / \mathrm{l}$, and/or more than $9 \mathrm{ml} / \mathrm{kg}$ blood were sampled since birth or the previous transfusion. In spontaneously breathing infants with $\mathrm{FIO}_{2}<0.4$ and older than 2 weeks, cutoff values were haematocrit 0.32 and haemoglobin $110 \mathrm{~g} / \mathrm{l}$ with, and 0.27 and $90 \mathrm{~g} / \mathrm{l}$, respectively, without signs of anaemia. Within these guidelines, decisions on timing and volume of transfusion were made by the neonatologists in clinical charge, blind to the infant's group assignment. Diagnostic blood loss was recorded meticulously. Treatment failure was defined as transfusion or venous haematocrit $<0.32$ during rhEPO treatment.

Oral iron supplement, $2 \mathrm{mg}$ a day, was recommended to start on day 14 of life and to be adjusted according to serum ferritin concentration, provided oral feeding was tolerated.

Haematocrit in venous blood and blood packs was measured by centrifugation. Reticulocyte count was 'normalised' to a haematocrit of 0.45 by multiplying the count by the actual haematocrit and dividing by 0.45 . Erythropoietin antibodies were sought using an enzyme-linked immunosorbent assay (ELISA). ${ }^{13}$

\section{STATISTICAL ANALYSIS}

The odds ratio for transfusion need compared with no transfusion was calculated for various 
Table 1 Median (quartile) blood loss, transfusion rate and failure (= transfusion or haematocrit $<0 \cdot 32$ ) rate in rhEPO treated VLBW infants

\begin{tabular}{|c|c|c|c|c|c|c|}
\hline Centre & $\begin{array}{l}\text { Infants } \\
\text { treated }(n=)\end{array}$ & $\begin{array}{l}\text { Blood loss } \\
(\mathrm{ml} / \mathrm{kg} / \text { day })\end{array}$ & $\begin{array}{l}\text { Iron supply } \\
\text { (mg/kg/ } \\
6 \text { weeks) }\end{array}$ & $\begin{array}{l}\text { Infants } \\
\text { transfused } \\
(n(\%))\end{array}$ & $\begin{array}{l}\text { Transfusions } \\
(n=)\end{array}$ & $\begin{array}{l}\text { Failure rate } \\
(n(\%))\end{array}$ \\
\hline $\begin{array}{r}1 \\
2 \\
3 \\
4 \\
5 \\
6 \\
6 \\
7 \\
8 \\
9 \\
10 \\
11 \\
12\end{array}$ & $\begin{array}{r}22 \\
20 \\
15 \\
11 \\
11 \\
10 \\
8 \\
6 \\
5 \\
5 \\
5 \\
2\end{array}$ & $\begin{array}{l}1.27(0.68 ; 1.81) \\
1.10(0.65 ; 1.44) \\
0.57(0.50 ; 1.66) \\
1.37(0.75 ; 3.75) \\
1.15(0.53 ; 1.81) \\
1.02(0.31 ; 1.38) \\
1.83(0.99 ; 2.81) \\
0.44(0.36 ; 0.51) \\
1.18(0.88 ; 5.16) \\
0.64(0.57 ; 1.20) \\
0.40(0.35 ; 0.56) \\
2.15 ; 3.80\end{array}$ & $\begin{array}{l}36(30 ; 41) \\
53(39 ; 61) \\
49(23 ; 56) \\
72(61 ; 76) \\
28(18 ; 39) \\
17(16 ; 20) \\
51(14 ; 61) \\
57(45 ; 59) \\
73(60 ; 103) \\
45(44 ; 63) \\
52(52 ; 65) \\
0 ; 177\end{array}$ & $\begin{array}{r}16(73) \\
12(60) \\
2(13) \\
6(55) \\
6(55) \\
7(70) \\
4(50) \\
1(17) \\
2(40) \\
1(20) \\
2(40) \\
1(50)\end{array}$ & $\begin{array}{r}33 \\
21 \\
2 \\
8 \\
13 \\
10 \\
4 \\
1 \\
4 \\
1 \\
2 \\
4\end{array}$ & $\begin{array}{l}16(73) \\
13(65) \\
5(33) \\
7(64) \\
9(82) \\
9(90) \\
4(50) \\
4(67) \\
3(60) \\
1(20) \\
5(100) \\
1(50)\end{array}$ \\
\hline
\end{tabular}

categorised factors. Exact $\mathbf{P}$ values were computed for testing that the odds ratio for (stratified) $2 \times 2$ contingency tables was 1 . Homogeneity of the odds ratios across the centres was analysed by Zelen's exact test. Multivariate Cox's proportional hazard method (forward selection procedure) was used to evaluate the impact of several factors on transfusion free time. The factor blood loss was obtained by calculating the total blood loss from birth to the first transfusion, divided by birthweight and the corresponding number of days. In case of no transfusion, time from birth to the end of study was taken. The MannWhitney U test was used to compare the transfused and untransfused groups with regard to continuous variables. All $\mathbf{P}$ values are two tailed and considered significant, if $\mathrm{P}<0.05$. Statistical analyses were carried out using the Statistical Analysis System (SAS Institute, Cary, North Carolina, USA) and the Statistical Software for Exact Nonparametric

Table 2 No (\%) of infants with blood transfusions for various categorised prognostic or time dependent factors and corresponding odds ratios with and without adjustment for centre effects (univariate analysis)

\begin{tabular}{|c|c|c|c|c|c|}
\hline Factor & Stratum & $\begin{array}{l}\text { Infants } \\
\text { evaluable } \\
(n=)\end{array}$ & $\begin{array}{l}\text { Infants } \\
\text { transfused } \\
(n(\%))\end{array}$ & $\begin{array}{l}\text { Odds ratio } \\
\text { unadjusted } \\
P \text { value }\end{array}$ & $\begin{array}{l}\text { Odds ratio } \\
\text { centre adjusted } \\
P \text { valuet }\end{array}$ \\
\hline \multirow{2}{*}{$\begin{array}{l}\text { Blood loss } \\
(\mathrm{ml} / \mathrm{kg} / \text { day })\end{array}$} & & 61 & $49(80 \cdot 3)$ & \multirow{2}{*}{$\begin{array}{l}17 \cdot 45 \\
\quad P<0.001\end{array}$} & \multirow[t]{2}{*}{$\begin{array}{l}38.07 \\
P<0.001\end{array}$} \\
\hline & $<1 \cdot 0$ & 58 & $11(19 \cdot 0)$ & & \\
\hline \multirow[t]{3}{*}{ Birthweight (g) } & $750-999$ & 34 & $27(79 \cdot 4)$ & \multirow{3}{*}{$\begin{array}{l}11 \cdot 22 \\
P<0.001 \\
3.05 \\
P=0.026\end{array}$} & \multirow{3}{*}{$\begin{array}{c}32 \cdot 43 \\
P<0.001 \\
5 \cdot 05 \\
P=0.005\end{array}$} \\
\hline & $1000-1249$ & 43 & $22(51 \cdot 2)$ & & \\
\hline & $1250-1499$ & 43 & $11(25 \cdot 6)$ & & \\
\hline \multirow{2}{*}{$\begin{array}{l}\text { Gestational age } \\
\text { (weeks) }\end{array}$} & $\leqslant 28$ & 47 & $33(70 \cdot 2)$ & \multirow{2}{*}{$\begin{array}{l}4.02 \\
P<0.001\end{array}$} & \multirow[t]{2}{*}{$\begin{array}{l}4 \cdot 68 \\
P=0.001\end{array}$} \\
\hline & $>28$ & 73 & $27(30 \cdot 0)$ & & \\
\hline \multirow[t]{2}{*}{ Initial haematocrit } & $\leqslant 0 \cdot 48$ & 66 & $40(60 \cdot 6)$ & \multirow{2}{*}{$\begin{array}{l}2 \cdot 62 \\
P=0.017\end{array}$} & \multirow{2}{*}{$\begin{array}{l}2 \cdot 72 \\
P=0.026\end{array}$} \\
\hline & $>0.48$ & 54 & $20(37 \cdot 0)$ & & \\
\hline \multirow{2}{*}{$\begin{array}{l}\text { Initial reticulocyte } \\
\text { count }(\%)\end{array}$} & $\leqslant 9$ & 67 & $41(61 \cdot 2)$ & \multirow{2}{*}{$\begin{array}{l}2 \cdot 73 \\
P=0.017\end{array}$} & \multirow{2}{*}{$\begin{array}{l}2 \cdot 18 \\
P=0.139\end{array}$} \\
\hline & $>9$ & 41 & $15(36 \cdot 6)$ & & \\
\hline \multirow[t]{2}{*}{ Ventilation } & Yes & 58 & $35(60 \cdot 3)$ & \multirow{2}{*}{$\begin{array}{l}2.35 \\
P=0.028\end{array}$} & \multirow{2}{*}{$\begin{array}{l}3.02 \\
P=0.022\end{array}$} \\
\hline & No & 61 & $24(39 \cdot 3)$ & & \\
\hline \multirow{2}{*}{$\begin{array}{l}\text { Initial serum protein } \\
(\mathrm{g} / \mathrm{l})\end{array}$} & $\leqslant 45$ & 44 & $29(65 \cdot 9)$ & \multirow{2}{*}{$\begin{array}{l}2.47 \\
P=0.032\end{array}$} & \multirow{2}{*}{$\begin{array}{l}2 \cdot 00 \\
P=0.157\end{array}$} \\
\hline & $>45$ & 66 & $29(43 \cdot 9)$ & & \\
\hline \multirow{2}{*}{$\begin{array}{l}\text { Iron supplementation } \\
(\mathrm{mg} / \mathrm{kg} / 6 \text { weeks })\end{array}$} & $\leqslant 50$ & 52 & $29(55 \cdot 8)$ & \multirow{2}{*}{$\begin{array}{l}1 \cdot 09 \\
P=1 \cdot 0\end{array}$} & \multirow{2}{*}{$\begin{array}{l}0.46 \\
P=0.305\end{array}$} \\
\hline & $>50$ & 41 & $22(53 \cdot 7)$ & & \\
\hline \multirow{2}{*}{$\begin{array}{l}\text { Initial serum ferritin } \\
(\mu \mathrm{g} / \mathrm{l})\end{array}$} & $<150$ & 56 & $30(53 \cdot 6)$ & \multirow{2}{*}{$\stackrel{0.93}{P=1.0}$} & \multirow[t]{2}{*}{$\begin{array}{l}0.89 \\
P=0.971\end{array}$} \\
\hline & $\geqslant 150$ & 47 & $26(55 \cdot 3)$ & & \\
\hline
\end{tabular}

^Exact $P$ value for testing that the odds ratio is 1 for $2 \times 2$ tables.

tExact $P$ value for testing that the odds ratio is 1 for $2 \times 2$ tables stratified by centre.

Homogeneity of odds ratios across centres was not rejected by Zelen's exact test $(P>0 \cdot 1)$ for any of the analysed factors with the exception of initial reticulocyte count.
Inference (Cytel Software Corp, Cambridge, MA, USA).

\section{Results}

CENTRE EFFECTS

Sixty $(50 \%)$ of the 120 rhEPO treated infants received at least one transfusion during the treatment period. Diagnostic blood loss, oral iron supplementation, transfusion rate, and failure rate in the participating centres are shown in table 1 . Five centres contributed $5 \%$ or less of the total number of 120 infants each, which gives a wide variability in transfusion rate and may make interpretation difficult. Considering the three large centres only, which contributed more than $10 \%$ of the infants each, the transfusion rates ranged from $13 \%$ to $73 \%$ representing the lowest and the highest transfusion rates among all 12 participating centres. In four of five centres with a transfusion rate below $50 \%$, transfused infants received one transfusion only, whereas in six of seven centres with a transfusion rate $\geqslant 50 \%$ infants were transfused more than once. Thus a high transfusion rate per centre predicted a high transfusion rate per infant (table 1).

\section{INDIVIDUAL FACTORS}

Median (quartiles) birthweight was $1260 \mathrm{~g}$ $(1135-1378 \mathrm{~g})$ in untransfused and $1040 \mathrm{~g}$ $(920-1211 \mathrm{~g})$ in transfused infants $(P<0 \cdot 001)$. Transfusion rates were inversely related to the infants' birthweight and gestational age (table 2). Sampling loss (median; quartiles) was lower $(P<0.001)$ in untransfused $(0.54 \mathrm{ml} / \mathrm{kg}$ a day; $0.43-0.88 \mathrm{ml} / \mathrm{kg}$ a day) than in transfused infants $(1.48 \mathrm{ml} / \mathrm{kg}$ per day; $1 \cdot 10-2 \cdot 13 \mathrm{ml} / \mathrm{kg} \mathrm{a}$ day). Transfusion need was significantly lower in infants with a blood loss $<1 \mathrm{ml} / \mathrm{kg}$ a day compared with those losing $\geqslant 1 \mathrm{ml} / \mathrm{kg}$ a day (table 2). Considering the centre effect, the impact of sampling blood loss and birthweight on transfusion need was even more pronounced (table 2). Twenty eight infants had been transfused before entry to the study (before day three of life). Twenty one (75\%) of these received additional transfusion during the study. Of the 92 infants without a transfusion before study entry, $39(42 \%)$ were transfused during rhEPO treatment. Of the 60 infants without any transfusion during the study, seven $(12 \%)$ had been transfused before entry; of the 60 infants transfused during treatment, $21(35 \%)$ had been transfused before entering the study.

\section{CONCOMITANT DISEASES AND TREATMENT}

Twenty four $(41 \%)$ transfused and $37(62 \%)$ untransfused infants were not ventilated. Thirty five $(60 \%)$ ventilated and $24(39 \%)$ non-ventilated infants received blood transfusions. Of the 28 infants ventilated for four days or longer, $78 \%$ were transfused. Ten of the 14 infants reported to have severe infections (septicaemia, meningitis, septic arthritis) were transfused. Ninety five infants received theophylline and/or caffeine. In this group 
transfusion rate was $56 \%$ compared with $28 \%$ in the group of infants not treated with theophylline or caffeine $(P=0.013)$.

\section{HAEMATOLOGICAL FACTORS}

In infants with initial reticulocyte counts $\leqslant 9 \%$, transfusion need was higher $(61 \%$ vs $37 \%)$ than in the complementary subgroup (table 2 ). Similarly, the transfusion need was $37 \%$ vs $61 \%$ in infants with initial haematocrits $>0.48$ and $\leqslant 0 \cdot 48$, respectively. Median decrease in corrected reticulocyte count from baseline to final visit was $-3.4 \%$ in the group without transfusion and $-0.5 \%$ in the transfused group. However, final values were almost identical. After three weeks of life, the fall in haematocrit was more pronounced in untransfused infants. Transfusion need was lower in infants with total serum protein concentration $>45 \mathrm{~g} / 1$ than in those with initial values $\leqslant 45 \mathrm{~g} / 1$ $(44 \%$ vs $66 \%$ ). Serum protein concentrations remained lower in transfused than in untransfused rhEPO treated infants throughout the study period. At an age of 6 weeks, screening for erythropoietin antibodies was uniformly negative.

\section{IRON SUPPLEMENTATION}

Cumulative iron supplementation (median and quartiles) was $46 \cdot 4 \mathrm{mg} / \mathrm{kg}(32 \cdot 7-59 \cdot 2 \mathrm{mg} / \mathrm{kg})$ in the untransfused group and $39.2 \mathrm{mg} / \mathrm{kg}$ $(21 \cdot 6-58.7 \mathrm{mg} / \mathrm{kg})$ in the transfused infants, which did not differ significantly. The percentage of transfused infants was not different for the groups with initial ferritin values below and above $150 \mu \mathrm{g} / \mathrm{l}$ or with iron supplementation below and above $50 \mathrm{mg} / \mathrm{kg}$ bodyweight (table 2). Serum ferritin concentrations decreased faster in untransfused than in transfused infants.

\section{PROGNOSTIC MODELS}

The multivariate analysis of the correlation between the transfusion free time and the covariates revealed that the retrospective model with blood loss, birthweight, and initial haematocrit was most explanatory for blood transfusions in rhEPO treated VLBW infants (table 3, model I). If only prognostic factors obtainable at the start of the study were considered, the model with birthweight, initial

Table 3 Multivariate Cox's proportional hazard model showing effect of various independent covariates on time to first transfusion

\begin{tabular}{lcccc}
\hline Covariate & $\begin{array}{l}\text { Regression } \\
\text { coefficient }\end{array}$ & $\begin{array}{l}\text { Relative } \\
\text { risk }\end{array}$ & $\begin{array}{l}95 \% \text { Confidence } \\
\text { interval }\end{array}$ & $\begin{array}{l}P \\
\text { value }\end{array}$ \\
\hline Model I (prognostic and concomitant factors, assessed on day 42) & & \\
Blood loss [ml/kg/day] & 1.021 & 2.777 & $2.077 ; 3.713$ & 0.0001 \\
Birthweight [100 g] & -0.191 & 0.826 & $0.712 ; 0.958$ & 0.0117 \\
Baseline haematocrit [\%] & -0.046 & 0.955 & $0.914 ; 0.999$ & 0.0449 \\
Model II (prognostic factors only, assessed on day & 3 ) & & \\
Birthweight [100 g] & -0.256 & 0.774 & $0.652 ; 0.919$ & 0.0035 \\
Initial haematocrit [\%] & -0.048 & 0.953 & $0.911 ; 0.997$ & 0.0362 \\
Gestational age [weeks] & -0.171 & 0.843 & $0.715 ; 0.994$ & 0.0427 \\
\hline
\end{tabular}

†Covariate adjusted relative risk $=\exp$ (regression coefficient).

*Obtained from Wald's $\chi^{2}$ test with 1 degree of freedom.

Note that a relative risk greater than 1 indicates an increased risk towards the need for transfusion with increasing values of the covariate, whereas a relative risk below 1 indicates an increasing risk with decreasing values. haematocrit, and gestational age was most predictive for transfusion need (table 3, model II). Predictably, higher birthweight, gestational age, and initial haematocrit prolonged the transfusion free time and reduced transfusion need.

\section{Discussion}

The causes of anaemia and need for transfusion in preterm infants include:

(1) the initial endowment with blood in the infant at birth reflected by the initial red cell mass;

(2) the magnitude of blood losses, related to severity and duration of intensive care;

(3) erythropoietic failure after preterm delivery.

These variables may be influenced by placental transfusion, easier in vaginal delivery than in Cesarean section, by centre-specific variations in phlebotomy and in transfusion volume administered, and by individual factors.

There are two phases of transfusion need after preterm delivery: (1) replacement of losses during intensive care and (2) transfusion for refractory anaemia resulting from erythropoietic failure and amenable by the use of rhEPO with appropriate iron and nutritional supplementation. In all but one ${ }^{10}$ previous report, the potency of rhEPO in reducing transfusion need during the first phase has been quite insufficient. When attempts have been made to use rhEPO as an alternative to transfusion for the second phase, where the objective is to prevent or perhaps correct the refractory anaemia of prematurity, variably successful results have been reported. 4-12 14-20 This reflects not only different study designs but also centre and patient specific differences. Our findings highlight the great heterogeneity of clinical features and management in the participating centres, and underline the tremendous importance of the infant's birthweight or gestation, and the impact of diagnostic blood loss on the need for transfusions.

Our transfusion criteria were less strict than in some other trials ${ }^{9-11}$ and this may have influenced our transfusion rate. Although all participants adhered to the transfusion guidelines, the transfusion rate varied considerably among the centres. This may be explained by the fact that the neonatologist assessed clinical signs of anaemia such as distended abdomen, apnoeic spells, and failure to thrive, which are all 'weak' diagnostic criteria and depend on the physician's experience. In some centres treatment failure (defined as transfusion or haematocrit $<0.32$ ) resulted from transfusion only, but never from a low haematocrit. In these centres infants were evidently transfused because of 'clinical' signs of anaemia or because of high sampling blood loss without having noticeably lowered haematocrit. Unfortunately, measurement of red cell mass and 'available oxygen' are not widely available in preterm infants. The lack of a transfusion 'target' in neonatal management is a very serious problem because if insufficient red cells are 
given, oxygen transport remains impaired with a possibly major negative impact on lung function and need for intensive support. ${ }^{21}$

Disease severity after preterm delivery is related to the cumulated diagnostic blood loss. This is strongly influenced by intercentre variation of phlebotomy practice and, in turn, influences perceived transfusion need. ${ }^{1122}$ The variation in sampling loss among the centres may reflect differences in frequency of monitoring tests and availability of micromethods, as well as patients' acuity of illness. Infants who were transfused before study entry before day 3 of life, had a higher risk to be transfused during the treatment period. Some of them may have sustained perinatal haemorrhages, some probably were just sicker than the untransfused infants. This is confirmed by the observation that infants needing a transfusion had a longer time on the ventilator and that most infants with nosocomial infection were transfused.

Holland et al found lower initial haemoglobin concentrations in symptomatic preterm babies than in asymptomatic infants. ${ }^{23}$ Kinmond et al reported that allowing a placental transfusion improves postnatal lung adaptation, reduces the severity of respiratory distress, and reduces transfusion need during the first weeks of life. ${ }^{24}$ This seems to be confirmed by our finding that a high initial haematocrit predicted a better rhEPO response.

The rhEPO response may also be influenced by the remaining endogenous erythropoietin production. Infants who needed a transfusion during rhEPO treatment had lower reticulocyte counts at the start and during the first three weeks of the treatment, possibly indicating suppressed endogenous erythropoiesis by transfusion. ${ }^{25}$ In adults theophylline attenuates endogenous erythropoietin production in health and after renal transplantation, ${ }^{26}$ which effect could not be confirmed in preterm infants. ${ }^{27}$ In our study the transfusion rate was significantly higher in infants treated with theophylline or caffeine. As apnoeic spells may cause repeated blood gas analyses, treatment with theophylline or caffeine, and red cell transfusion, our data do not indicate whether these drugs may influence endogenous erythropoietin production and limit the rhEPO response.

Nutrition, including the adequacy of iron and protein supply, also influences the adequacy of erythropoiesis in response to rhEPO. Protein deficiency impairs erythropoiesis. ${ }^{28} 29$ Bechensteen et al were able to reduce the transfusion need in preterm infants with rhEPO and high additional protein intake. ${ }^{4}$ In our trial serum protein concentrations were higher during the entire study period in untransfused infants than in the transfused group. This finding may indicate that the protein intake in infants requiring transfusion was too low for adequate erythropoiesis with rhEPO or that low protein concentrations reflect severe illness. Nutritional adequacy may have varied considerably among patients in different centres. Presumably the transfused packs of red cells did not contain enough plasma protein to augment body protein stores.
Decreasing serum iron and ferritin concentrations ${ }^{4-9} 111216$ indicate mobilisation of iron by stimulated erythropoiesis. On the other hand, erythropoiesis requires enough iron to be incorporated in red cells. ${ }^{30}$ Therefore, iron supplementation can enhance or limit the effect of rhEPO. Serum ferritin concentrations fell in infants with and without transfusion. This decrease was less pronounced in transfused infants, reflecting parenteral iron intake with transfused red cells. The drop in ferritin concentration in the group without transfusion suggests that oral iron intake was too low during rhEPO-stimulated erythropoiesis.

Brown $\mathrm{et} \mathrm{al}^{3}$ reported that the best predictor of late transfusion, after 2 weeks of age, in infants not treated with rhEPO was gestational age below 30 weeks. We found birthweight to be the predominant predictor of the need for transfusion during rhEPO treatment. The smallest and sickest infants may loose all their blood to the laboratory within six weeks ${ }^{22}$ and the impact of diagnostic sampling increases with decreasing birthweight.

In summary, the need for transfusion in rhEPO treated infants depends on the infants' birthweight, gestational age, initial haematocrit, and centre specific factors such as cumulative blood loss and supplementation with iron and protein. We conclude that to improve rhEPO treatment in very low birthweight infants diagnostic losses must be minimised by strict indication and by micromethods, for preventing iron and protein deficiency, and for objective guidelines on when and how much to transfuse.

\section{Appendix:}

FACILITIES AND COWORKERS IN THE SECOND EUROPEAN ThEPO MULTICENTRE TRIAL

Participating centres (listed in order of the number of infants enrolled into the trial):

Virchow-Klinikum, Humboldt-Universität Berlin, Germany (Rolf F Maier, Michael Obladen, Klaus Abraham, Christoph Bührer, Cornelia Domeyer)

Universität Heidelberg, Germany (Otwin Linderkamp, Johannes Pöschl)

Universität Zürich, Switzerland (Gabriel Duc, Peter Baeckert, Anne M Bucher, Hans U Bucher)

Olgahospital Stuttgart, Germany (Gertrud Hieronimi, Martin Wagner, Martin Kroll, Helmut Gulde)

Royal Maternity Hospital, Belfast, Northern Ireland (Henry L Halliday, Mary G O'Connor, Frank A Casey, B Garth McClure)

Universitätsklinikum Steglitz, Freie Universität Berlin, Germany (Hans T Versmold, Marius Bartsch)

Centre hospitalier universitaire Cochin Port-Royal, Paris, France (Guy Moriette, Catherine Clamadieu, Michèle MonsetCouchard, Philippe Mussat)

Universität Münster, Germany (Gerhard Jorch, Heike Rabe, Erik Michel, Susanne Lindner). Université Catholique de Louvain, Bruxelles, Belgium (Gaston Verellen, Ch Debauche, D Moulin, S Clement) 
University Hospital Nijmegen, the Netherlands (Ben A Semmekrot, Louis A A Kollée). Charité, Humboldt Universität, Berlin, Germany (E Ludwig Grauel, Heidrun Weigel, Steffi Ledwon)

Queen Mother's Hospital, University of Glasgow, Scotland (Barbara M Holland, Graham Stewart).

Steering Committee: Michael Obladen, Rolf F Maier (Klinikum Rudolf Virchow, Freie Universität Berlin, Germany), and Paul Scigalla (Boehringer Mannheim, Germany).

Consultant in haematology: University of Wales, Cardiff, Wales (Charles A J Wardrop).

Consultant in statistics: Boehringer Mannheim, Germany (Diethelm Messinger).

Data management and evaluation: AFB Comstat, Berlin, Germany (Werner Wierich, Johann Brüning, Richard Vonk).

This study was supported by Deutsche Forschungsgemeinschaft (SFB 174/A9) and by Boehringer Mannheim, Germany.

1 Levy GJ, Strauss RG, Hume H, Schloz L, Albanese MA, Blazina J, et al. National survey of neonatal transfusion practices: I. Red blood cell therapy. Pediatrics 1993; 91: 523-9.

2 Strauss RG. Transfusion therapy in neonates. Am $\mathcal{f}$ Dis Child 1991; 145: 904-11.

3 Brown MS, Berman ER, Luckey D. Prediction of the need for transfusion during anemia of prematurity. $\mathcal{f}$ Pediatr 1990; 116: 773-8

4 Bechensteen AG, Hågå $P$, Halvorsen $S$, Whitelaw $A$, Liestol K, Lindemann R, et al. Erythropoietin, protein, and iron supplementation and the prevention of anaemia of prematurity. Arch Dis Child 1993; 69: 19-23.

5 Carnielli V, Montini G, Da Riol R, Dall'Amico R, Cantarutti F. Effect of high doses of human recombinant erythropoietin on the need for blood transfusions in preterm infants. F Pediatr 1992; 121: 98-102.

6 Emmerson AJB, Coles HJ, Stern CMM, Pearson TC: Double blind trial of recombinant human erythropoietin in preterm infants. Arch Dis Child 1993; 68: 291-6.

7 Maier RF, Obladen M, Scigalla P, Linderkamp O, Duc G Hieronimi G, et al. The effect of epoetin beta (recombinan human erythropoietin) on the need for transfusion in veryow-birth-weight infants. N Engl f Med 1994; 330: 1173-8.

8 Messer J, Haddad J, Donato L, Astruc D, Matis J. Early treatment of premature infants with recombinant human erythropoietin. Pediatrics 1993; 92: 519-23.

9 Meyer MP, Meyer JH, Commerford A, Hann FM, Sive AA Moller G, et al. Recombinant human erythropoietin in the treatment of the anemia of prematurity: Results of a double-blind, placebo-controlled study. Pediatrics 1994 93: 918-23.

10 Ohls RK, Osborne KA, Christensen RD. Efficacy and cost analysis of treating very low birth weight infants with analysis of treating very low birth weight infants with erythropoietin during their first two weeks of life: A ran421-6.

11 Shannon KM, Keith III JF, Mentzer WC, Ehrenkranz RA Brown MS, Widness JA, et al. Recombinant human erythropoietin stimulates erythropoiesis and reduces erythrocyte transfusions in very low birth weight preterm infants. Pediatrics 1995; 95: 1-8.
12 Soubasi V, Kremenopoulos G, Diamandi E, Tsantali C, Tsakiris D. In which neonates does early recombinant human erythropoietin treatment prevent anemia of prematurity? Results of a randomized, controlled study. Ped Res 1993; 34: 675-9.

13 Kientsch-Engel R, Hallermayer K, Dessauer A. Methods for measuring erythropoietin and erythropoietin antibodies using ELISA technique. Contrib Nephrol 1989; 76: 100-5.

14 Beck D, Masserey E, Meyer M, Calame A. Weekly intravenous administration of recombinant human erythropoietin in infants with the anaemia of prematurity. Eur $\mathcal{F}$ Pediatr 1991; 150: 767-72.

15 Halpérin DS, Wacker P, Lacourt G, Félix M, Babel J-F, Aapro $M$, et al. Effects of recombinant human erythropoietin in infants with the anemia of prematurity: A pilot poietin in infants with the anemia

16 Kivivuri SM, Heikinheimo M, Teppo A-M, Siimes MA. Early rise in serum concentration of transferrin receptor induced by recombinant human erythropoietin in verylow-birth-weight infants. Pediatr Res 1994; 36: 85-9.

17 Obladen M, Maier R, Segerer H, Grauel EL, Holland BM, Stewart G, et al. Efficacy and safety of recombinant human erythropoietin to prevent the anaemias of prematurity. European randomized multicenter trial. Contrib Nephrol 1991; 88: 314-26.

18 Ohls RK, Christensen RD. Recombinant erythropoietin compared with erythrocyte transfusion in the treatment of anemia of prematurity. F Pediatr 1991; 119: 781-8.

19 Shannon KM, Mentzer WC, Abels RI, Freeman P, Newton $\mathrm{N}$, Thompson $\mathrm{D}$, et al. Recombinant human erythropoietin in the anemia of prematurity: Results of a placebopoietin in the anemia of prematurity: Results of a place

20 Shannon KM, Mentzer WC, Abels RI, Wertz M, ThayerMoriyama J, Li WY, et al. Enhancement of erythropoiesis Moriyama $\mathrm{J}, \mathrm{Li}$ WY, et al. Enhancement of erythropoiesis infants: A pilot study. $\mathcal{F}$ Pediatr 1992; 120: 586-92.

21 Wardrop CA, Holland BM, Jacobs S, Jones JG. Optimization of the blood for oxygen transport and tissue perfusion in critical care. Postgrad Med $\mathcal{F}$ 1992; 68 (suppl 2): S2-6.

22 Obladen M, Sachsenweger M, Stahnke M. Blood sampling in very low birth weigth infants receiving different levels of intensive care. Eur F Pediatr 1988; 147: 399-404.

23 Holland BM, Jones JG, Wardrop CAJ. Lessons from the anemia of prematurity. Hematol Oncol Clin North Am 1987; 1: 355-66.

24 Kinmond S, Aitchison TC, Holland BM, Jones JG, Turner TL, Wardrop CAJ. Umbilical cord clamping and preterm infants: A randomised trial. BMf 1993; 306: 172-5.

25 Brown MS, Phibbs RH, Dallman PR. Postnatal changes in fetal hemoglobin, oxygen affinity, and 2,3-diphosphoglycerate in previously transfused preterm infants. Biol Neonate 1985; 48: 70-6.

26 Bakris GL, Sauter ER, Hussey JL, Fisher JW, Gaber AO, Winsett R. Effects of theophylline on erythropoietin production in normal subjects and in patients with erythrocytosis after renal transplantation. $N$ Engl f Med 1990; 323: 86-90.

27 Gonzalez MT, Sherwood JB, Brion LP, Schulman M Erythropoietin levels during theophylline treatment in premature infants. $\mathcal{F}$ Pediatr 1994; 124: 128-30.

28 Okano M, Ohnota H, Sasaki R. Protein deficiency impairs erythropoiesis in rats by reducing serum erythropoietin concentration and the population size of erythroid precursor cells. $₹$ Nutr 1992; 122: 1376-83.

29 Kivivuori SM, Järvenpää AL, Salmenperä L, Viinikka $L$ Siimes MA Erythropoiesis of very low-birth-weight Siimes MA. Erythropoiesis of very low-birth-weight infants dependent on prenatal grow.

30 Brugnara C, Chambers LA, Malynn E, Goldberg MA, Kruskall MS. Red blood cell regeneration induced by subcutaneous recombinant erythropoietin: iron-deficient ery-
thropoiesis in iron-replete subjects. Blood 1993; 81: 956-64. 